\title{
TUGAS
}

\section{FILSAFAT ILMU}

"MERINGKAS MODERASI DAKWAH SYEKH YUSUF AL-MAKASSARP”
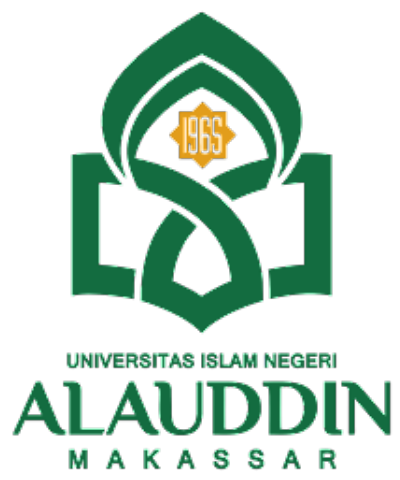

DISUSUN OLEH :

NAMA : St. Nur Aisa

NIM $\quad: 50400121017$

KELAS : $1 \mathrm{MD}-\mathrm{A}$

DOSEN PEMBIMBING :

Prof. Dr. MUSTARI MUSTAFA, M. Pd

PRODI MANAJ EMEN DAKWAH

FAKULTAS DAKWAH DAN KOMUNIKASI

UNIVERSITAS ISLAM NEGERI ALAUDDIN MAKASSAR

MODERASI DAKWAH SYEKH YUSUF AL-MAKASSARI 


\section{ABSTRAK}

Pesan dakwah Syekh Yusuf Al-Makassari mencerminkan nilai-nilai Islam yang damai dan toleran terhadap kelompok agama lain sehingga jauh dari kes an anarkis dan ekstrim (Ansori, 2018). Seminar ini bertujuan untuk mengekplorasi kekayaan metode dan pesan dakwah Syekh Yusuf Al-Makassari yang moderat, damai dan toleran terhadap pemeluk agama lainnya serta memberi kesempatan yang sama pada setiap ras dan suku bangsa.

Kata Kunci: moderat; dakwah; Syekh Yusuf.

\section{PENDAHULUAN}

Syekh Yusuf Tajul Khalwaty, atau lebih dikenal dengan nama Tuanta Salamaka (Tuan Kita yang Selamat) lahir di Moncongloe, Gowa pada 3 J uli 1626 atau bertepatan dengan 8 Syawal 1036 Hijriah dengan nama Muhammad Yusuf. Tambahan gelar Syekh disematkan padanya usai belajar ke timur tengah dan menunaikan ibadah Haji di Tanah Suci, Mekah.

Ayahnya, Abdullah adalah sufi keturunan Arab dari Aceh. Sedangkan Ibunya, Siti Aminah Itulbiani Daeng Kunjung Karaeng Baji adalah putri bangsawan Gallarang Moncong Loe di era Sultan Alauddin, Raja Gowa XIV. Meski terlahir di Gowa, namun Syekh Yusuf menghabiskan sebagian besar hidupnya berdakwah di negeri orang.

Sementara di Afrika Selatan, negara tempat meninggalnya, yang dimakamkan adalah sorban dan jubah beliau. Begitu juga makam yang ada di Banten, Sumenep dan Srilanka. Bukti lain ketokohan Syekh Yusuf adalah gelar pahlawan nasional yang diberikan oleh dua negara lintas benua, yakni Republik Indonesia dan Republik Afrika Selatan. Afrika Selatan memberikan penghargaan Gold-Order of the Companions of Oliver Reginald.

Tambo pada 27 September 2005, yakni penghargaan tertinggi yang 
ditujukan untuk tokoh asing yang berjasa bagi Negara Afrika Selatan. Mandela menyebut Syech Yusuf sebagai tokoh yang menginspirasi perjuangannya menentang praktik politik apartheid. Pemyataan itu disampaikan Nels on Mandela dalam peringatan 300 tahun kedatanganSyekh Yusuf di Cape Town, Afrika Selatan pada Tahun 1994. Dia mengatakan, "Dia adalah putra Afrika Selatan dan insprirasi perjuangan anti-apartheid. Dia adalah inisiator terbentuknya komunitas Afrika Selatan. Saya mendapatkan inspirasi dari beliau, bahwa kulit hitam dan kulit putih adalah setara, bahwa bangsawan dan budak tidaklah berbeda.Apa yang membedakan manusia di depan Tuhan adalah kedalaman imannya”.

Seminar tentang Tuanta Salamaka Syekh Yusuf Al-Makassari sebelumnya sudah pernah digelar pada 10 November 2011 di Makassar oleh Konsulat J enderal Republik Indonesia. Namun hingga saat ini, belum ada seminar digelar berkaitan dengan corak dakwah Syekh Yus uf Al-Makassari yang moderat, damai dan toleran.

Menurut Ansori, "Pesan dakwah tentang kajian etika religius Al-Makassari melambangkan dan mencerminkan nilainilai Islam yang damai, toleran dan menolak intoleransi, ramah, dan tidak anarkisme dan antiterorisme terhadap golongan-golongan lain”.

Kons titusi tertulis ini menyatakan bahwa semua golongan agama dan suku yang berada di Madinah mempunyai hak, perlakuan dan kewajiban yang sama, tanpa harus memaksakan kehendak kepada golongan lain baik dari segi keagamaan maupun sosial.

Metode dakwah Syekh Yusuf sesuai dengan teladan yang dicontohkan Rasulullah SAW.Dakwah yang sangat moderat, adaptif dan menjunjung tinggi nilai-nilai toleransi. Corak ini sangat berbeda dengan corak dakwah mayoritas ulama populer hari ini di Indonesiayang mengedepankan gaya orasi keras dan diksi yang menyulut perbedaan, serta menggunakan ayat-ayat 'pedang'. 


\section{GAMBARAN SINGKAT}

Seminar ini akan menghadirkan akademisi universitas dari berbagai negara yang telah melakukan ris et mengenai Syekh Yusuf Al-Makass ari seperti Malaysia, Inggris, Belanda, Amerika Serikat, Australia dan lain sebagainya. Paling tidak ada tiga scholar daritiganegara yang menjadi pembicara utama, yakni Indonesia, Srilanka dan Afrika Selatan. Dan tidak menutup kemungkinan akan bertambah.

Output yang diharapkan adalah prosiding dan atau jurnal ilmiah yang terindeks di pangkalan data bereputasi serta buku yang juga dapat ditemukan di platform terkemuka duniatentang moderasi dakwah Syekh Yusuf Al-Makassari. Dampak lain dari seminar ini adalah kunjungan wisata mancanegara ke Kabupaten Gowa dalam rangka menghadiri seminar dan mengunjungi makam Syekh Yusuf di Kobbang, Lakiung.Selain itu, dimungkinkan pula bagi Bupati Gowa untuk menyampaikan hasil-hasil seminar tentang Moderasi Dakwah Syekh Yusuf Al-Makassari dalam kuliah umum di Oxford University atau Harvard University. Kuliah umum tersebut merupakan langkah tindak lanjut yang diharapkan dari s eminar internasional ini.

\section{J ADWAL KEGIATAN}

Kegiatan ini direncanakan pada 3 Juli 2020. Tanggal ini dipilih untuk memperingati 394 tahun kelahiran Syekh Yusuf Al-Makassari di Kabupaten Gowa. Dengan harapankegiatan tersebut memberikan input pendapatan daerah bagi Kabupaten Gowa dan masyarakat Gowa dari sektor pariwisata. Yusuf di Kobbang dan Benteng Somba Opu.

\section{PENUTUP}

Artikel ini sebagai gambaran awal terkait moderasi dakwah Syekh Yusuf Al Makassari. Semoga rencana kegiatan ini, dapat bermanfaat bagi pengembangan keilmuan danpembangunan masyarakat Kabupaten Gowa pada khususnya, dan Sulawesi Selatan. 


\section{DAFTAR PUSTAKA}

Mustari. M. (2011). Agama dan bayang-bayang etis Syaikh Yusuf AlMakassary.

https://books.google.com/books/about/Agama_dan_Bayang_Bayang_Etis_Syaik h_Yusuf.html?id=mhReDwAAQBAJ . LKIS PELANGI AKSARA. 